\title{
Økonominyheder på Facebook: Er usikkerhed på arbejdsmarkedet og fordelingen af samfundskagen vigtigere end konjunkturer?'
}

AF POUL THØIS MADSEN

\section{Resumé}

På basis af 2 x 100 økonomiske nyheder, der blev kommenteret eller liket på Facebook i 2012 og 2015, undersøger denne artikel, hvilke typer af økonomiske spørgsmål mediebrugere interagerer over. Det viser sig særligt at være økonomiske nyheder, der handler om udviklingen i indkomstfordeling og på arbejdsmarkedet. Det står i modsætning til den hidtidige internationale forskning i mediernes dækning af økonomiske forhold, der har betonet betydningen af konjunkturnyheder. Fremtidig forskning bør derfor analysere mediernes dækning af indkomstfordeling og arbejdsmarked og de mulige konsekvenser, som disse typer af nyheder kan have for mediebrugeres økonomiske og politiske dispositioner.

\section{Introduktion}

Er mediebrugerne overhovedet interesseret i økonomiske nyheder? Og i givet fald hvilken type af økonomiske nyheder? Det er de to hovedspørgsmål, der søges besvaret i denne artikel. Det er vigtige spørgsmål, fordi det er en grundantagelse i forskningen, at mediebrugeres politiske og økonomiske dispositioner er stærkt påvirket af økonomidækningen (se Schiffrin, 2015, for en oversigt over denne forskning med særligt henblik på mediernes dækning af finanskrisen). 
Analysen i artiklen er baseret på 2 x 100 økonomiske artikler fra henholdsvis $2012 \mathrm{og} 2015$. Det nye metodiske begreb i forhold til den hidtidige forskning i mediernes dækning af økonomi er, at de analyserede nyheder er identificeret via Facebook. Artiklen handler imidlertid ikke om sociale medier; Facebook er alene brugt som et værktøj til at indsamle nye typer af data. Ved fortolkningen af resultaterne er det imidlertid nødvendigt at konsultere dele af litteraturen om sociale medier, fordi det er omdiskuteret, hvad de sociale medier gør ved den virkelighed, der kanaliseres gennem dem, og hvordan denne virkelighed derfor skal fortolkes.

I det følgende gives først et overblik over den hidtidige forskning i økonomiske nyheder med særlig vægt på mediebrugerne. Herudfra gives der også et bud på, hvilke typer af økonomiske nyheder der er forskningsmæssigt belæg for kan interessere Facebook-brugere. Dernæst redegøres der for metoden. Som det tredje punkt redegøres der for de væsentligste resultater. Endelig diskuteres resultaterne af undersøgelsen blandt andet i form af mulige implikationer for fortolkningen af den hidtidige forskning og udviklingen af den fremtidige.

\section{Hvad ved vi på forhånd om medieforbruget af økonomiske nyheder, og hvilke resultater forventer vi?}

Hovedparten af forskningen i økonomidækningen har søgt at kortlægge mønstre i dækningen af økonomiske forhold - primært i de skrevne medier. Hovedsporet i denne forskning har været at påvise mediernes forkærlighed for negative økonomiske nyheder eller det, som Kollmeyer betegner som et 'bad-newsbias perspective' (2014:433).

En vigtig del af forskningen i økonomidækningen har derfor ganske logisk handlet om mulige konsekvenser af et sådant bias. Hovedresultatet har været, at når medierne giver et for negativt billede af, hvordan det går med den økonomiske udvikling, så påvirker det mediebrugerne mere negativt, end det burde, hvilket kan påvirke deres økonomiske dispositioner, og hvem de stemmer på (centrale ældre bidrag er Blood og Phillips, 1995, og Goidel og Langley, 1995). 
Modellen bag denne forskning er baseret på følgende forståelse:

$ø$ konomidækning $\rightarrow$ [mediebrugeren] $\rightarrow$ økonomiske og politiske konsekvenser

Som det fremgår, står mediebrugeren i parentes. Det skyldes, at det antages, at mediebrugeren og hans/hendes udvælgelse af økonomiske nyheder har samme karakter som den generelle økonomidækning: Hvis nyhederne overvejende er negative, så vil mediebrugerne overvejende vælge at læse negative økonomiske nyheder. Det kan virke som en rimelig antagelse, men den efterlader ikke meget spillerum til mediebrugernes frie valg. Det kan jo tænkes, at de netop ikke er interesserede i negative økonomiske nyheder, eller at de har større interesse for andre typer af økonomiske nyheder, eller at en væsentlig del af mediebrugerne surfer uden om de økonomiske nyheder. Den problematik er imidlertid aldrig undersøgt empirisk, hvilket udgør en af de vigtigste foranledninger til dette studium.

For at vide, om de økonomiske nyheder faktisk påvirker mediebrugerne, er vi derfor nødt til at komme tættere på det faktiske forbrug af økonomiske nyheder, end tilfældet har været i den hidtidige forskning. Allerede Parker (1997) påpegede, at der her var et hul i forskningen og fremhævede, at vi ved alt for lidt om 'economic learning' blandt det, som han kalder 'audience' (1997:15). Det er det hul, jeg søger at mindske, men dog langtfra formår at lukke med den empiri, der præsenteres nedenfor.

En hovedårsag til, at der har været så lidt blik for den enkelte mediebruger, er, at størstedelen af den hidtidige forskning har fokuseret på det generelle mønster i økonomidækningen og på henholdsvis forbrugere og vælgere set som en samlet gruppe. Forskningen har søgt at påvise mulige generelle konsekvenser for især forbrugerforventninger og stemmeafgivelse af den generelle økonomidækning i den generelle medieflade. Derved er den enkelte mediebruger kun indirekte repræsenteret, og der måles kun meget indirekte på medieforbruget.

Kun en særdeles begrænset del af forskningen i økonomidækning har fokuseret direkte på mediebrugeren. Det eneste eksempel herpå, som jeg har kunnet finde i min litteratursøgning, er 
Haller og Norpoth (1997), der gennem deres fortolkning af resultaterne af en spørgeskemaundersøgelse for den amerikanske $ø$ konomi er kommet ganske tæt på den enkelte mediebruger gennem svaret på spørgsmålet: 'have you heard of any favorable or unfavorable changes in business conditions?' (1997:558). Ud fra svaret på det spørgsmål vælger Haller og Norpoth lidt dristigt at konkludere, at halvdelen af befolkningen ifølge eget udsagn slet ikke har 'hørt' nogen økonomiske nyheder (1997:555), hvorfor store dele af befolkningen i princippet slet ikke kan påvirkes direkte af økonomidækningen.

En begrænset del af forskningen har bestået i eksperimenter, hvor udvalgte informanter er blevet konfronteret med udvalgte virkelige økonomiske nyheder (Pruitt m.fl., 1988), eller hvor udvalgte respondenter har deltaget i en spørgeskemaundersøgelse, hvor de er blevet bedt om at tage stilling til en konstrueret positiv og negativ nyhed, som Helle Svensson har gjort det $\mathrm{i}$ en af artiklerne i sin ph.d.-afhandling fra 2016. Af de tre nævnte bidrag er det således kun Haller og Norpoth, der, omend i særdeles begrænset omfang, har forholdt sig til faktiske mediebrugere og deres frie valg af nyheder om økonomi.

Det er således ikke undersøgt i den hidtidige forskning, hvilken type af økonomiske nyheder mediebrugerne opsøger ud af egen drift. Selvom der derfor er tale om et helt uudforsket område, er det alligevel muligt ud fra den hidtidige forskning at udkrystallisere nogle mønstre i mediernes økonomidækning, der kan anvendes til at kategorisere de økonomiske nyheder, som har brugernes særlige interesse på Facebook.

Et af de nyere bidrag i forskningen om, hvordan økonomidækningen kan påvirke forbrugernes forventninger, er skrevet af van Dalen, deVreese \& E. Albæk (2015), der også giver en oversigt over den tidligere forskning på området. Den forskning indikerer, at det første forventede mønster er en betydelig mængde 'konjunkturnyheder', som afspejler, at mediebrugerne er interesserede i at finde ud af: Går det op eller ned med økonomien?

En anden del af forskningen går ud fra, at mediebrugerne anvender de økonomiske nyheder til at danne sig en forventning om, hvordan det går og vil komme til at gå på arbejdsmarkedet (jf. Pruitt et al., 1998, men særligt Garz, 2013 og 2014). Den type af økonomiske nyheder og andre, der relaterer til arbejdsmarkeds- 
forhold i bredere forstand, er den anden hovedkategori og kan sammenfattes under betegnelsen 'arbejdsmarked'.

Tager man derimod udgangspunkt i den del af økonomidækningsforskningen, som kan betegnes som 'politisk økonomi' (Durham, 2007; Kollmeyer, 2004; Tracy, 2012), så er fokus på, hvem der taber og vinder ved den økonomiske udvikling og som følge af gennemførslen af diverse reformer. Denne tredje type af nyheder betegnes i det følgende som 'indkomstfordelingsnyheder'.

\section{Metode: Udvælgelsen af nyheder om økonomi delt på Facebook}

I det følgende gennemgås metoden relativt dybdegående, fordi der er en række begrænsninger og fortolkningsproblemer ved empirien. I forbindelse med sit forskningsprojekt 'deviralenyheder.dk' har Filip Wallberg, SDU, udviklet en metode til at høste nyheder, der stammer fra danske mediers hjemmesider, men som også dukker op på Facebook. Wallberg har ud fra mine dessiner foretaget de to søgninger, som undersøgelsen baserer sig på. Der søges efter økonomiske ord i artiklernes rubrik og manchet.

Første trin var en pilotsøgning, der tog udgangspunkt i en bruttoliste på 44 makroøkonomiske søgeord. Pilotsøgningen viste, at der var en betydelig mængde nyheder om økonomiske temaer, der enten bliver delt, kommenteret eller liket på Facebook (kaldet interaktioner), hvorfor der var basis for at gå videre. Det næste trin var at reducere antallet af 'økonomiske' søgeord for at mindske antallet af nyheder, der enten intet har med økonomi at gøre (økonomiske ord og vendinger bruges ofte i ikke-økonomiske sammenhænge i medierne, viste pilotsøgningen) eller har særdeles begrænset interaktion. Det skete ved at fokusere på de søgeord, som pilotsøgningen viste afdækkede økonominyheder med mest interaktion. Slutresultatet var 15 makroøkonomisk orienterede søgeord: Skat, Krise, Økonom, Vækst, Ulighed, Løn, Arbejds, Ledige, Dumping, Penge, Finanslov, Euroen, Fattige, Rige og Kontanthjælp (søgestrengen er i appendiks nedenfor). 
Den endelige søgning førte til en bruttoliste af nyheder. Baseret på en analyse af de nyheder, som havde størst interaktion i henholdsvis 2012 og 2015, udvalgte jeg 100 (makro)økonomiske nyheder for hvert af de to år. Der er ingen særlig begrundelse for at vælge 100 nyheder per år, udover at de udgør et vist volumen, samtidig med at det analytiske arbejde stadig er overkommeligt.

Der opereres med to år af flere grunde. For det første er det en udbredt antagelse i litteraturen, at økonomidækningen ændrer sig, når konjunkturerne gør det. Centrale bidrag som Alsem et al. (2008) og van Dalen, de Vreese og E. Albæk (2015) når frem til, at der er en tendens til, at både op- og nedture overdrives af medierne. Derfor er der valgt et år, 2012, med lavkonjunktur $(0,2 \%$ vækst i BNP) og et andet år, 2015, med en betydeligt bedre konjunktur (1,6\% vækst i BNP) (begge væksttal er hentet fra Statistikbanken). Hvis der kan påvises ens resultater på tværs af en konjunkturcykel og under skiftende regeringer, er det mere sandsynligt, at der er tale om en gennemgående systematik. Omvendt vil det også være interessant, hvis der kan påvises en ændring fra 2012 til 2015 i, hvilke typer af økonomiske nyheder der interageres over, og hvor eventuelle skift i typen af nyheder måske kan tilskrives en ændret konjunktur.

Ved indkredsningen af de 2 x 100 økonomiske nyheder blev en række nyheder sorteret fra. Bruttolisten af nyheder var således på henholdsvis 125 i 2012 og 169 i 2015. At der sker en frasortering skyldes for det første, at stort set enslydende nyheder går igen $\mathrm{i}$ forskellige medier. For det andet frasorteredes historier, som slet ikke handler om makroøkonomiske spørgsmål: 'Betaler topskat og har boet i Danmark i 12 år: Nu står han til at blive smidt ud'. Den nyhed handler ikke om topskat, men om flygtninge- og indvandrerpolitik. Topskatten udgør blot en del af den journalistiske 'krog.' For det tredje er der set bort fra en række historier, som slet ikke har noget at gøre med makroøkonomiske spørgsmål: 'Hun er 315 millioner rigere: BT har mødt lotto-vinderen'. Der ses i tråd hermed også bort fra historier, som enten kun lugter lidt af økonomi, eller som er af mikroøkonomisk natur uden makroøkonomiske implikationer. Det vil sige, at der ses bort fra

- Forbrugerstof og skattefiduser 
- Flygtninge- og indvandrerhistorier, som ikke handler om øonomi

- Mikroorienterede erhvervsnyheder

- Historier, der fremhæver kongefamiliens økonomiske privilegier

Et af de springende punkter har været, hvorvidt såkaldte human interest-historier skulle medtages. Eftersom den slags på papiret ikke-makroøkonomiske nyheder i høj grad har mediebrugernes interesse, kan de tænkes at have potentiale til at påvirke mediebrugernes økonomiske og politiske forventninger og i sidste instans dispositioner. Derfor er nyheder af typen 'Enlig mor til fire på kontanthjælp: Tania får 23.000 i støtte efter skat' medtaget $\mathrm{i}$ analysen.

Analysen opererer altså ikke med en bestemt deduktiv definition af, hvad en økonomisk nyhed er. Wallberg, der har indsamlet de 2 x 100 økonomiske nyheder fra en række internetmedier, definerer heller ikke præcist, hvad han forstår ved et medie, men tabel 1 viser de medier, som de 100 økonomiske nyheder primært kommer fra i hvert af de to år.

Tabel 1. Hvor kommer økonominyhederne på Facebook især fra? Antal nyheder ud af 100 i 2012 og 2015.

\begin{tabular}{|l|l|l|l|l|l|l|}
\hline Medier & Berlingske & Politiken & tv2.dk & dr.dk & eb.dk & Information \\
\hline 2012 & 21 & 18 & 2 & 14 & 9 & 7 \\
\hline 2015 & 9 & 10 & 25 & 12 & 7 & 7 \\
\hline
\end{tabular}

Som et led i analysen skete der endelig en kodning. At kode kan rumme et betydeligt usikkerhedsskabende element af fortolkning, og man lader derfor ofte assistenter kode uafhængigt af hinanden for at tjekke, hvorvidt man kan stole på kodningen. Herved kan man tjekke for interkodereliabilitet.

I dette tilfælde er der sket en relativt simpel kodning af forfatteren selv, idet nyhederne alene kategoriseres som arbejdsmarkeds-, indkomstfordelings- eller konjunkturnyheder. Det vil sige hvis der står noget om arbejdsmarkedsforhold, lønforhold, dagpenge og kontanthjælp og lignende, så er der tale om en arbejdsmarkedsnyhed. Når der er tale om, at der er grupper, der mister eller får en indkomst, så er det en indkomstfordelingsnyhed. I de tilfælde, hvor nyheden i høj grad handler om, at økonomien er 
på vej op eller ned eller har stabiliseret sig, så er der tale om en konjunkturnyhed.

Den eneste komplikation opstår, når nyheden falder ind under flere kategorier: Hvornår er der eksempelvis primært tale om en arbejdsmarkedsnyhed, og hvornår er det også en indkomstfordelingsnyhed (en både og-nyhed)? På grund af den usikkerhed, det kan give, fokuseres der nedenfor kun på helt klare tendenser i data.

Der er otte principielt mulige fordelinger: tre rene kategorier, alle tre kategorier på én gang, en blanding af henholdsvis indkomstfordeling og arbejdsmarked, indkomstfordeling og konjunktur, arbejdsmarked og konjunktur og endelig uden for kategori.

En analyse af de kategoriserede økonomiske nyheder giver et mere detaljeret billede af, hvad de tre typer af nyheder kan dække over. Indkomstfordelingsnyheder handler typisk om:

- Den markedsmæssige fordeling af samfundskagen (fattigdom, rigdom, marginalisering)

- Den statslige omfordeling (kontanthjælp, dagpenge, skattesystemet, finanslov, reformer af henholdsvis overførselsindkomster, afgifter og skatter)

- Social dumping

- Privilegier

Arbejdsmarkedsnyheder handler om:

- Arbejdstid, arbejdsintensitet, arbejdsløshed og mangel på arbejdskraft

- Social dumping

- Overenskomster

- Dagpenge

- Arbejdsmarkedskonflikter

- Lønudvikling

Konjunkturnyheder handler om:

- Mangel på arbejdskraft, øget arbejdsløshed og øget/mindsket beskæftigelse

- Flere/færre på dagpenge og kontanthjælp 
- Ændring af indkomstfordeling som følge af skiftende konjunkturer

- Skift i den økonomiske politik som følge af konjunkturerne

- Krise og opsving

- Udviklingen i offentlig gæld og underskud

\section{Resultater: Mønstre i Facebook-brugernes relationer til økonomiske nyheder}

I det følgende undersøges det, hvilke mønstre der er i de økonomiske nyheder, som skaber mest interaktion på Facebook. Først undersøges det, hvordan de nyheder, der skaber mest aktivitet, fordeler sig på de tre kategorier: konjunktur, arbejdsmarked og indkomstfordeling. For at kunne gå ned i de mere detaljerede mønstre zoomes der derefter ind på de fem mest delte nyheder $\mathrm{i}$ henholdsvis 2012 og 2015. Gennemgangen slutter med en tematisk opdeling af de 2 x 100 nyheder.

Det mest slående resultat er, at økonomiske nyheder rent faktisk skaber en betydelig aktivitet på Facebook - faktisk på niveau med den Facebook-aktivitet, der skabes ved ikke-økonomiske historier, som har særlig gennemslagskraft. Hvor Wallberg (2012) fremhævede, at 897 generelle nyhedshistorier i perioden 1. juni 2011 til 1. juni 2012 skabte over 1000 interaktioner, viser den nye undersøgelse, at der for året 2012 var 50 økonomiske nyheder, der hver især havde over 1.000 interaktioner.

Spørgsmålet er imidlertid, hvilken type af økonomiske nyheder det er tilfældet for. Som det fremgår af tabel 2, er det mod forventning ikke primært konjunkturnyheder, der skaber aktivitet på Facebook. Af de 100 mest interagerede økonomiske nyheder i hvert af de to år er der ifølge tabel 2 kun henholdsvis syv og otte egentlige konjunkturnyheder (af typen 'Bageri erkender: Det er ikke et problem at skaffe arbejdskraft'). Den dominerende type af nyhed (mere end $7 \mathrm{ud}$ af $10 \mathrm{i}$ begge år) handler helt eller delvist om indkomstfordelingsspørgsmål af typen: Hvem vinder, eller hvem taber ved eksempelvis en reform? Det gælder især i forhold til spørgsmål om kontanthjælp og dagpenge. 
Tabel 2. Antal økonominyheder (= procent) fordelt på centrale kategorier i 2012 og 2015.

\begin{tabular}{|l|l|l|l|}
\hline & Indkomstfordeling & Arbejdsmarked & Konjunktur \\
\hline 2012 & 76 & 42 & 7 \\
\hline 2015 & 74 & 52 & 8 \\
\hline
\end{tabular}

Hvilke nyheder har så haft den største interaktion? Det fremgår af nedenstående tabel med de fem økonomiske nyheder, hvilke der har affødt størst interaktion i hvert af de to år.

Tabel 3. De 5 økonominyheder med mest interaktion i henholdsvis 2012 og 2015.

\begin{tabular}{|l|l|l|l|l|}
\hline 2012 & Overskrift & Likes & Delinger & Kommentarer \\
\hline & $\begin{array}{l}\text { 'Joachim B: Pladderhumanisme } \\
\text { fastholder folk på kontanthjælp' }\end{array}$ & 3518 & 67 & 4070 \\
\hline $\begin{array}{l}\text { 'Joachim B.: Mænd er mere ambi- } \\
\text { tiøse, og det afspejler lønnen' }\end{array}$ & 2705 & 1813 & 3073 \\
\hline & 'Får 4,4 millioner kroner i dagpenge' & 2483 & 515 & 4093 \\
\hline & $\begin{array}{l}\text { 'Enlig mor til fire på kontanthjælp: } \\
\text { Tania får 23.000 i støtte efter skat' }\end{array}$ & 1436 & 441 & 4853 \\
\hline 2015 & 'Baconkrise under opsejling i EU' & 1822 & 1320 & 3009 \\
\hline & $\begin{array}{l}\text { 'Flemming Jensens opråb: Holsts } \\
\text { eftervederlag svarer til 8 års løn for } \\
\text { en pædagogmedhjælper' }\end{array}$ & 16057 & 4441 & 1871 \\
\hline & $\begin{array}{l}\text { 'Sænk arbejdstiden og drop arbejds- } \\
\text { hysteriet' }\end{array}$ & 16884 & 919 & 1990 \\
\hline & $\begin{array}{l}\text { 'Gratis sommerlejr mangler fattige } \\
\text { børn: Hvor er de henne?' }\end{array}$ & 4572 & 9585 & 1950 \\
\hline & $\begin{array}{l}\text { 'Mangler sin kontanthjælp: Gimi } \\
\text { Levakovic raser over systemet' }\end{array}$ & 11635 & 747 & 2537 \\
\hline & 'Jeg er arbejdsløs - ikke idiot' & 10829 & 2129 & 1317 \\
\hline
\end{tabular}

Wallberg (2012:15 og 17) peger på, at en nyhed, der har en høj grad af interaktion på Facebook, typisk er 'solid', 'sensationel', fokuserer på en politiker eller en politisk sag, der er let at forstå. Som det fremgår af tabel 3, så minder gængse Facebook-nyheder med en høj grad af interaktion om de økonomiske nyheder, der særligt tiltrækker sig opmærksomhed på Facebook. Linaa Jensen (2017) peger på, at der især deles nyheder på Facebook som følge af 'medfølelse eller selvfølelse', hvilket også passer ind i fortolkningen af de fleste af de 10 nyheder, selvom de er økonomiske. 
Derimod likes sensationer og det konfliktuelle ifølge samme kilde. $^{2}$

Anden forskning som Hermida (2014) peger på, at forargelse er en væsentlig 'driver' for delingen af nyheder på de sociale medier. Den iagttagelse stemmer også fint overens med flere af de 10 mest delte nyheder, som enten i sig selv vækker forargelse, eller hvor man er forarget over andres forargelse.

Manglen på sensation kan omvendt være med til at forklare, hvorfor konjunkturnyheder fylder ret lidt på Facebook. De er sværere at gøre sensationelle eller til en politisk sag, der har en bestemt politiker i centrum: 'Joachim B. Olsen: Nu må der gang i hjulene igen' - en konstrueret nyhed - vil næppe tiltrække sig den store opmærksomhed på Facebook.

En tematisering af de mest interagerede nyheder underbygger, at indkomstfordeling og arbejdsmarked er centrale emner for mediebrugerne, som det fremgår af tabel 4. Der er næsten samme overordnede mønster i 2015 som i 2012.

Tabel 4. De centrale debattemaer blandt de 100 økonomiske nyheder med størst interaktion i henholdsvis 2012 og 2015. Antal nyheder under temaet.

\begin{tabular}{|l|l|l|}
\hline & 2012 & 2015 \\
\hline Er kontanthjælpen for høj eller for lav/tilpas? & 16 & 21 \\
\hline Dagpengeproblemet ska/løses & 13 & 0 \\
\hline Er dagpengesystemet nu OK eller ej? & 0 & 8 \\
\hline $\begin{array}{l}\text { De rige bliver rigere + } \\
\text { de privilegierede har for mange privilegier }\end{array}$ & 7 & 10 \\
\hline Fattigdomsdebat + de fattige bliver fattigere & 5 & 11 \\
\hline Skatten er for høj (topskat i parentes) & $7(1)$ & $10(3)$ \\
\hline Er social dumping et problem eller ej? & $\begin{array}{l}\text { (Vejlegården-sagen) }) \\
\text { (Ryanair) }\end{array}$ & 5 \\
\hline $\begin{array}{l}\text { Flygtninge og indvandrere er en økonomisk } \\
\text { belastning }\end{array}$ & 0 & 7 \\
\hline
\end{tabular}

Det viser, at de nyheder, der har offentlighedens bevågenhed, tilsyneladende er uafhængige af konjunkturer og regeringens sammensætning (der kom en Venstre-regering til 28. juni 2015). Aktualitet er dog også en determinerende faktor, hvorfor det er ganske logisk, at dagpengedebatten i 2015 har flyttet sig til ikke længere at handle om dagpengereformen, men om, hvorvidt dagpengesystemet efter justeringerne fungerer godt nok. Tilsvarende er der i 2012 sagen om Restaurant Vejlegården, hvor fagfor- 
eningen forsøgte at få de ansatte over på en overenskomst. Den case er i 2015 skiftet ud med en ny, der i endnu højere grad har social dumping som omdrejningspunkt: debatten om arbejdsforholdene i Ryanair.

Fra de 100 nyheder i 2012 til de 100 nyheder i 2015 opstår der kun én helt ny økonomisk debat, der er en følge af den flygtningestrøm, som EU og dermed Danmark har oplevet. I den debat diskuteres ikke primært integrations- og flygtningeproblemer, men der fokuseres i stedet på en mere afgrænset del af problemstillingen, nemlig flygtninge og indvandrere som en egentlig økonomisk belastning. Der var fem nyheder herom i $2015 \bmod 0$ i 2012 blandt de 100 mest interagerede nyheder.

Interessant nok fylder en af de helt aktuelle økonomiske debatter, som det politiske parti Liberal Alliance i den grad har søgt at markedsføre, mod forventning ikke meget: Topskatten er i fokus i én nyhed i 2012 og tre i 2015. Derimod udgør nyheder om skattelettelser eller forøgelser en langt større andel af de 100 nyheder.

Det skal understreges, at de to debatter, der dominerer, drejer sig om dagpenge og kontanthjælp med særlig vægt på kontanthjælp i 2015. Samlet set udgør den type af nyheder lidt under en tredjedel i hvert af de to år. Det peger på, at usikkerhed i forbindelse med, hvordan arbejdsmarkedet fungerer i samspil med det offentlige sikkerhedsnet, er af central betydning for Facebookbrugerne. En konklusion, der underbygges af den opmærksomhed, der tildeles Vejlegården-sagen og Ryanair.

\section{Hvordan skal vi fortolke resultaterne?}

I det følgende fortolkes resultaterne ovenfor ud fra tre perspektiver: Hvad udtrykker de i sig selv? Hvilket lys kaster de på den hidtidige forskning? Hvilken fremtidig forskning peger resultaterne på?

Der er to empiriske hovedresultater: Det første resultat er, at der $e r$ betydelig interesse for økonomiske nyheder på Facebook, der har samfundsrelevans. Det er med andre ord muligt at skrive $ø$ konomiske nyheder om væsentlige samfundsforhold, som fænger. 
For det andet interesserer mediebrugerne på Facebook sig i høj grad for indkomstfordeling og arbejdsmarkedsforhold og i mindre grad for konjunkturdækning. Af den hidtidige forskning får man omvendt det indtryk, at mediebrugerne primært forholder sig til økonomistoffet for at afkode, om økonomien er på vej op eller ned. Her peger resultaterne på, at det gør mediebrugerne også, men at der er en langt større interesse for at vide noget om, hvem der vinder og taber som følge af økonomiens udvikling og politiske tiltag.

Det er især økonomiske historier, der har et konfliktperspektiv, som tiltrækker sig opmærksomhed. Det gælder formentlig også i forhold til forbruget af økonomiske nyheder uden for Facebook, men det bør selvsagt undersøges empirisk. De nye resultater peger endvidere på, at der er et behov for at undersøge, hvordan sådanne historier påvirker mediebrugerne. Hvad betyder det for deres syn på økonomien? Deres økonomiske dispositioner og den politiske stemmeafgivelse?

Styrken ved de ovenstående resultater er, at de udtrykker 'noget' om nogle mediebrugeres faktiske 'forbrug' af skriftlige økonomiske nyheder. Svagheden er indikeret ved, at forbrug netop står i gåseøjne, fordi vi stadig mangler fuld viden herom. Hvad vi ved er, at som minimum er en økonomisk orienteret overskrift blevet læst, liket og i nogle tilfælde kommenteret og delt. Vi ved ikke, om og i hvilken udstrækning den økonomiske nyhed er læst i sin helhed. Der er klart et behov for at undersøge det 'fulde' mediebrug.

En anden mangel, som fremtidig forskning burde søge at råde bod på, er, at der mangler viden om, hvem der interagerer over de økonomiske nyheder. Det kunne tænkes, at de mange nyheder om dagpenge og kontanthjælp i høj grad affødte interaktion på Facebook af dagpenge- og kontanthjælpsmodtagere, som i princippet har mere tid til at være aktive på de sociale medier, end tilfældet er for erhvervsaktive. Men reelt eksisterer der ikke en detaljeret viden ud over alder og køn (som det afrapporteres i den årlige medierapport fra Slots- og Kulturstyrelsen, 2016) om Facebook-brugere, og vi ved slet ikke noget om, hvordan fordelingen måtte være i forhold til forbruget af økonomiske nyheder.

En tredje mangel er, at det ikke fremgår, hvilke økonomiske nyheder Facebook-brugerne har valgt at se bort fra. Vi kender 
med andre ord ikke de økonomiske nyheder, som Facebookbrugerne slet ikke interagerer over. Der foreligger derfor heller ikke viden om, hvor mange økonomiske nyheder der rent faktisk er, eller hvorvidt de 2 x 100 nyheder minder meget eller lidt om tendensen i den samlede økonomidækning. Det kan eksempelvis tænkes, at en af forklaringerne på, at der interageres relativt lidt over konjunkturnyheder, er, at der skrives mindre om de økonomiske konjunkturer, end man skulle formode ud fra den hidtidige forskning. Det kunne derfor være interessant at afdække, hvor skævt eller dækkende et billede de 2 x 100 nyheder giver af den samlede økonomidækning.

Endelig ville man også kunne øge vores viden betydeligt gennem en komparativ analyse. Ikke mindst kunne det være interessant at undersøge, hvilke debatter der interageres over på Facebook i mindre veludviklede velfærdsstater som den britiske og ikke mindst den amerikanske. Måske er der i disse to lande en langt større interesse for konjunkturnyheder på Facebook, da den menige brite eller amerikaner er mere afhængig af den økonomiske udvikling, end tilfældet er i lande, der som Danmark har et mere finmasket sikkerhedsnet. Hvor interessante resultaterne end måtte fremstå, så udgør Danmark i et komparativt perspektiv en atypisk case i kraft af en meget lille økonomi og en meget veludviklet velfærdsstat.

\section{Konklusion: Økonomiske nyheder om konflikter og usikkerhed har en gang på Facebook}

Hovedresultatet er, at der er økonomiske nyheder, som optager en betydelig mængde Facebook-brugere. Et andet vigtigt resultat er, at Facebook-brugerne især er optagede af systemiske spørgsmål om, hvordan samfundskagen fordeles, og hvordan arbejdsmarkedet fungerer. Det er tankevækkende nok også de spørgsmål, som udgør udgangspunktet for de relativt få bidrag inden for økonomidækningsforskningen, som har et mere politiskøkonomisk og konfliktorienteret perspektiv end hovedstrømmen af forskningen i økonomi og medier.

Et tredje vigtigt resultat er, at kun et fåtal af de mest interagerede nyheder har at gøre med konjunktursituationen. Det er 
mere det spektakulære, kontroversielle og forargelige, men dog også systemiske, der bliver interageret over.

Derudover gør resultaterne én opmærksom på, at den hidtidige forskning har haft en blind plet ved at se bort fra mediebrugernes eget valg af økonomiske nyheder. Store dele af den hidtidige forskning i økonomidækningen har konkluderet, at mediebrugerne har en særlig forkærlighed for negative økonomiske nyheder uden at spørge dem om det rent faktisk også er tilfældet.

Som et minimum burde den fremtidige forskning i højere grad fokusere på, hvordan indkomstfordelingsnyheder og usikkerhederne på arbejdsmarkedet dækkes - ikke mindst komparativt. Derudover bør forskningen i højere grad afdække, hvordan den slags nyheder og en eventuel skæv afrapportering af dem kan tænkes at påvirke såvel mediebrugernes økonomiske såvel som politiske dispositioner.

Det er med andre ord nødvendigt at udvikle metoder til at komme endnu tættere på mediebrugerne, end det er lykkedes i dette studium, hvis man vil vide mere om forbruget af økonomiske nyheder og de mulige konsekvenser heraf. Her er der inspiration at hente fra de dele af medieforskningen, der går langt tættere på mediebrugerne, end der er tradition for i økonomidækningsforskningen, som mere har arbejdet ud fra armslængdeprincippet: deduktivt og positivistisk og kun i begrænset omfang kvalitativt.

\section{REFERENCER}

Alsem, Karel Jan, et al (2008). “The Impact of Newspapers on Consumer Confidence: Does Spin Bias exist?”, Applied Economics 40.5 (2008), pp. 531-539.

Blood, Deborah J. \& Peter C.B. Phillips (1995). "Recession Headline News, Consumer Sentiment, the State of the Economy and Presidential Popularity: A Time Series Analysis 1989-1993”, International Journal of Public Opinion Research 7.1, pp. 2-22.

Van Dalen, Arjen, Claes de Vreese \& Erik Albæk (2017). "Economic News Through the Magnifying Glass: How the Media Cover Economic Boom and Bust”, Journalism Studies 18.7 (2017), pp. 890-909.

Durham, Frank D. (2017). "Framing the State in Globalization: The Financial Times' Coverage of the 1997 Thai Currency Crisis”, Critical 
Studies in Media Communication 24.1 (2007), pp. 57-76.

Garz, Marcel (2013). “Unemployment Expectations, Excessive Pessimism, and News Coverage", Journal of Economic Psychology 34 (2013), pp. 156-168.

Garz, Marcel (2014). “Good News and bad News: Evidence of Media Bias in Unemployment Reports.” Public Choice 161.3-4 (2014), pp. 499515.

Goidel, Robert K. \& Ronald E. Langley (1995). "Media Coverage of the Economy and Aggregate Economic Evaluations: Uncovering Evidence of Indirect Media Effects”, Political Research Quarterly 48.2, pp. 313-328.

Haller, H. Brandon \& Helmut Norpoth (1997). "Reality Bites: News Exposure and Economic Opinion”, Public Opinion Quarterly, pp. 555-575.

Hermida, Alfred (2014). Tell Everyone: Why We share and Why It matters. Doubleday Canada.

Kollmeyer, Christopher J. (2004). “Corporate Interests: How News Media Portray the Economy", Social Problems 51(3), pp. 432-52.

Linaa Jensen, Jacob (2017). "Sensationer, skandaler eller blot kattekillinger", pov.international, 25.9.

Parker, Richard (1997). ”Journalism and Economics: The Tangled Webs of Profession, Narrative, and Responsibility in a Modern Democracy", Joan Shorenstein Center on the Press, Politics, and Public Policy, Harvard University, John F. Kennedy School of Government, Discussion Paper D-25. Cambridge, MA: Joan Shorenstein Center, Harvard University.

Pruitt, Stephen W., Robert J. Reilly \& George E. Hoffer. (1988). “The Effect of Media Presentation on the Formation of Economic Expectations: Some Initial Evidence”, Journal of Economic Psychology 9(3), pp. 31525.

Schiffrin, Anya (2015). "The Press and the Financial Crisis: A Review of the Literature", Sociology Compass, 9(8), pp. 639-653.

Slots- og Kulturstyrelsen (2016), Mediernes udvikling i Danmark 2016, http://slks.dk/mediernes-udvikling-2016/

Svensson, Helle M. (2016). Processing Economic News, ph.d.-afhandling, Centre For Journalism, University of Southern Denmark.

Tracy, James F. (2012). “Covering Financial Terrorism, the Greek Debt Crisis in the US News Media”, Journalism Practice 64(4), pp. 513-29.

Wallberg, Filip (2012), I like News, e-bog, udgivet af Wallberg selv https://itunes.apple.com/dk/book/i-like-news/id589405329?mt=11 


\section{APPENDIKS: SøGESTRENG}

Søgestreng: select * from (select title, link, year(date), date, likes, shares, comments, likes + shares + comments as total from stories left join longterm on stories.id = longterm.id where ((date $>$ "2014-12-31 23:59" and date < “2015-12-31 23:59") OR (date > “2011-12-31 23:59" and date < "2012-12-31 23:59)" OR (date > "2015-12-31 23:59" and date < “2016-12-31 23:59”) AND (title LIKE '\%skat\%' OR title LIKE ‘\%krise\%’ OR title LIKE ‘\%økonom\%’ OR title LIKE ‘\%vækst\%’ OR title LIKE ‘\% ulighed\%’ OR title LIKE ‘\%løn\%’ OR title LIKE ‘\%arbejds\%’ OR title LIKE ‘\% ledige \%’ OR title LIKE ‘\%dumping \%’ OR title LIKE ‘\%penge\%’ OR title LIKE ‘\%finanslov\%’ OR title LIKE ‘\% euroen \%' OR title LIKE ‘\%fattige\%' OR title LIKE ‘\%kontanthjælp\%' OR title LIKE '\% rige \%')) as inv where total $>0$ order by year(date) ASC, total desc.

\section{NOTER}

1 En varm tak går til min forskningsgruppe ved henholdsvis DMJX og AAU (CCWS), medieforskere fra hele landet, der gav kommentarer til et tidligt udkast af nærværende artikel på et møde i januar 2017, og til de to fagfællebedømmere ved Journalistica.

2 Linaa Jensens data er indtil videre kun publiceret i en populær sammenhæng som POV.

\section{FORFATTER}

Poul Thøis Madsen

Lektor ved Aalborg Universitet og docent ved Danmarks Medie- og Journalisthøjskole ptm@dmjx.dk 